DOI: https://dx.doi.org/10.4314/sinet.v44i1.11

\title{
Association of human papilloma Virus infection other than cervical cancer: Systematic Review and Meta Analysis
}

\author{
Habtamu Molla ${ }^{1, *}$, Habtamu Temesgen ${ }^{2}$ and Dereje Beyene ${ }^{3}$ \\ ${ }^{1}$ Lecturer in Medical Laboratory Department, Health Science College, Addis Ababa University, Addis \\ Ababa, Ethiopia. E-mail: habtamu.molla@aau.edu.et, \\ ${ }^{2}$ Lecturer in Department of Human Nutrition and Food Sciences, College of Health Science, Debre \\ Markos University, Debre Markos, Ethiopia. E-mail: habtamutem@gmail.com \\ ${ }^{3}$ Assisstance Professor in Molecular Genetics/Functional Genomics at Microbial, Cellular and \\ Molecular Biology Department, Addis Ababa University, Addis Ababa, Ethiopia. E-ail: \\ dereje.beyene@aau.edu.et
}

\begin{abstract}
Human Papilloma Virus (HPV) infection causes different cancer diseases. Cervical cancer is the most common HPV related disease. HPV infection also causes cancer of anus, vulva, vagina, penis, skin, bladder, prostate, breast, oral and others because the HPV virus is epitheliumtropic. But the association of HPV infection other than cervical cancer, for example breast cancer, bladder cancer, prostate cancer etc is still inconclusive. Thus, the objective of this review was to collect published information on HPV infection other than cervix to explore the pooled prevalence of HPV infection as well as related types of cancers. Publish research articles of HPV infection and cancer risks other than cervical cancer were systematically searched through Internet. The preferred reporting items for systematic review and meta-analysis guidelines were followed. Joanna Brigg's Institute Meta-Analysis of Statistics Assessment and Review Instrument (JBIMAStARI) adapted for cross sectional/case control study design was used for quality assessment of each individual study. A total of 22 studies were extracted and analyzed using STATA 14 . The random effect model was used to estimate the pooled prevalence; whereas subgroup analysis and meta-regression was performed to identify the probable source of heterogeneity. Both Egger's and Begg's tests were used to check publication bias. The totals of 486 studies were retrieved and 22 studies were included in this meta- analysis. The meta-analysis result showed that the pooled prevalence of HPV infection other than cervix was 34.36\% (95\% CI: 23.75, 44.97) with severe heterogeneity $\left(\mathrm{I}^{2}=99.5 \%\right.$; $\left.\mathrm{p}<0.001\right)$ with no publication bias. The highest pooled prevalence of HPV infection other than cervix was related to genital cancer which is $58.63 \%$ (95\% CI: 51.86, 65.39), followed by oral cancer $(47.15 \%$ with $95 \%$ CI: $19.67,74.63)$. Although cervical cancer is primarily HPV induced cancer which well articulated with so many researches, other cancer types (based on the location of the HPV infection) are also increasing across the world based on this systematic and meta-analysis study. HPV infection increases the risk of developing cancers other than cervical cancer.
\end{abstract}

Key words/phrases: HPV infection, HPV related cancers, Review

\section{INTRODUCTION}

Human Papillomavirus (HPV) is a group of viruses that are extremely common globally. HPV is a non-enveloped small (8000bp) DNA virus with circular double stranded DNA, mainly infects epithelia cells of skin and mucosal membrane (Münger, Baldwin et al. 2004, Asiaf, Ahmad et al. 2014).

There are more than 200 types HPV identified, of which many do not caused problems (Woodman, Collins et al. 2007). Based on the association between cancers, HPV types can be classified as high risk HPV and low risk HPV (Muñoz, Bosch et al. 2003). Infections with low risk HPV types like HPV 6, 11, 40, 42, 43, 44,
$54,61,70,72,81$ etc does not cause symptoms and disappear when the body builds immunity to the virus (Tadlaoui, Hassou et al. 2020). But infections with high risk HPV types like HPV 16, $18,31,33,35,39,45,51,52,56,58,59,68,73,82$ etc cause different cancers (Yete, D'Souza et al. 2018).

HPV infection causes different cancer diseases and cervical cancer is the most common HPV related disease (Serrano, Brotons et al. 2018). HPV infection also causes cancer of anus, vulva, vagina, penis, skin, bladder, prostate, breast, oral and others because the HPV virus is epitheliumtropic (Parkin 2006). But the association of HPV infection other than cervical cancers, for example

${ }^{*}$ Author to whom correspondence should be addressed. 
breast cancer, bladder cancer, prostate cancer etc is still inconclusive.

Cervical cancer is the fourth most common cancer in women (Small, Bacon et al. 2017). 70\% of cervical cancer is caused by HPV type 16 \& 18 (Bryan 2007). About $4.5 \%$ of all cancers worldwide $(630,000$ new cancer cases per year) are attributable to HPV: $8.6 \%$ in women and $0.8 \%$ in men (de Martel, Plummer et al. 2017). HPV infection and cervical cancer relations were well studied and already awareness was created about the risk. But HPV infection related cancers other than cervical cancer did not get attention among researchers, policy makers or in different charity organizations. Thus, the objective of this review was to collect published information on HPV infection other than cervix to explore the pooled prevalence of HPV infection as well as related types of cancers. This systematic analysis could directly help future research.

\section{METHODS}

\section{Searching strategies}

This systematic review and meta-analysis designed to estimate the pooled prevalence of HPV infection and related types of cancer risk. Initially systematic review and meta-analysis, including registered protocols were searched to avoid duplications and it was confirmed that there was no any review and meta-analysis was conducted to HPV infection and cancer risk other than cervix. Published research reports of HPV infection and cancer risks other than cervical cancer were searched. We systematically reviewed and analyzed published research articles to determine the pooled prevalence of HPV infection and its related cancer type. To identify published articles, major databases such as Pub med/Medline, Cochrane library, Goggle and Google scholar were used. In addition, reference lists were used. The key used in search was "prevalence" or "infection" and "HPV" and "risk cancer" and "HPV type". The search was conducted from September 1, 2020 to October 1, 2020. I followed the preferred reporting item for systematic review and meta-analysis (PRISMA) guideline during the systematic review (Liberati, Altman et al. 2009).

\section{Eligibility criteria}

All studies which report the prevalence of HPV infection and cancer risk, and case control and cross sectional study designs were included under this systematic review and meta-analysis. Articles published in English language and studies conducted worldwide were included. Published articles until September 1/2020 were eligible for this review. But studies difficult to access full text, not English language, studies which do not report specific outcome of HPV infection and studies done on cervical cancer were excluded from this systematic review and meta-analysis.

\section{Data abstraction}

Data were extracted using a standardized data extraction spreadsheet. In data extraction sheet study characteristics such as authors name, country, publication year, study design, sample size; prevalence of HPV infection; type of cancer were included.

\section{Quality Assessment of studies}

The Database search results were combined and duplicate articles were removed manually using Endnote (version X7). Joanna Briggs Institute meta-analysis of Statistics Assessment and Review Instrument (JBT-MAStARI) adapted for both cross sectional and case control study design was used (Schultz and Florence 2007). Three independent reviewers critically evaluated each individual paper. Discrepancies between those reviewers were solved by discussion. If not, a third reviewer was involved to resolve inconsistencies in between the two independent reviewers. Studies which score five and above from a total of 9 score were included in the final systematic review and meta-analysis.

\section{Outcome measurement}

This review and meta-analysis has two main outcomes. The primary outcome was prevalence of HPV infection and the second outcome was HPV infection related cancer types.

\section{Data analysis}

The extracted data were entered into an excel sheet and imported to STATA version 14 for meta-analysis. Heterogenicity among reported prevalence was assessed by using the inverse variance $\left(\mathrm{I}^{2}\right)$ with Cochran Q statistic of $25 \%, 50 \%$ and $75 \%$ as low, moderate and sever heterogenicity respectively with p-value less than 0.05 (Tate and Brown 1970). Random effect meta-analysis model was used to estimate the pooled prevalence of HPV infection. The forest plot was also used to visualize the presence of heterogenicity graphically. Possible differences 
between the studies were explored by sub-group analysis and meta-regression. The finding was presented using forest plot with respective odds ratio and 95\% confidence intervals. Evidence of publication bias was assesses using both Egger's and Begg's tests with p-value of less than 0.05 as a cutoff point to declare the presence of publication bias (Sutton, Abrams et al. 2000, Kontopantelis and Reeves 2010).

\section{RESULTS}

\section{Selection of studies}

A total of 486 articles searched through the electronic search of which 156 duplicate articles were excluded. From the remaining 330 articles, 306 articles were excluded after reading of titles and abstracts. Finally, 24 full text articles were assessed for eligibility criteria. Based on the predefined criteria and after criteria appraisal (two articles excluded) (Ammatuna, Giovannelli et al.
2008, Siegler, Shiner et al. 2017), 22 articles were included in the final analysis (Figure 1).

\section{Characteristics of included studies}

The total 22 articles were included in this meta-analysis and systematic review that meets the inclusion criteria. All the included studies were published from 2000 up to 2019. All included studies used either cross sectional or case control study design. A total of 8967cancer suspected individuals participated in these studies using an estimated sample size range from 30 (Makiyama, Hirai et al. 2013) up to 3393 (Zhao, Wu et al. 2018) to estimate the pooled prevalence of HPV infection and cancer risk other than cervix. From the total of 22 articles, 5 studies in USA; 3 study in India; 3 study in Iran; 1 study conducted in China; 1 study in Denmark; 1 study in England; 1 study in Germany; 1 study in Iraq; 1 study in Japan; 1 study in Mexico; 1 study in Netherland; 1 study in Oman; 1 study in Sweden and 1 study in Spain. The results were tabulated according to publication year (Table 1).

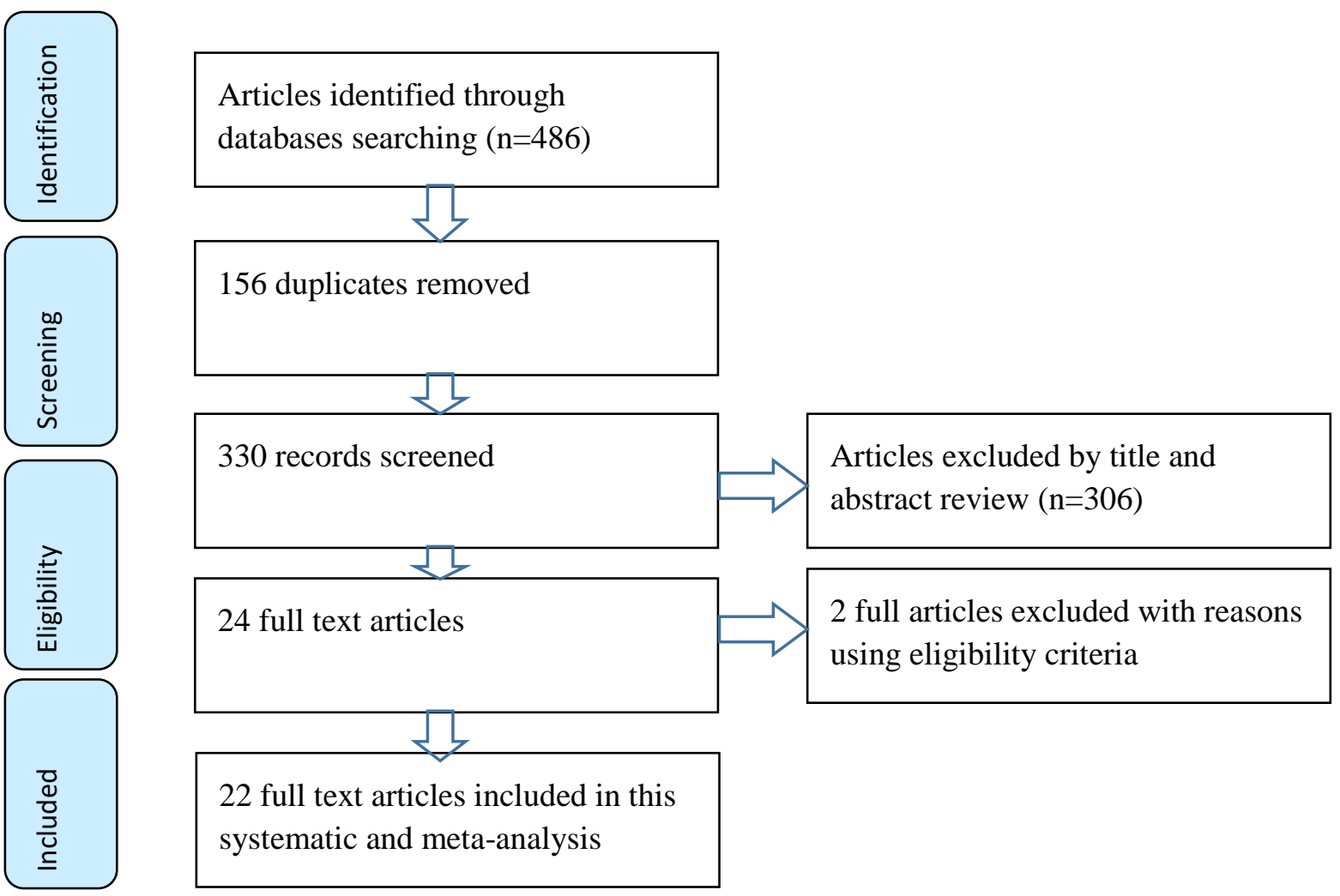

Figure 1. PRISMA flow diagram of included studies to estimate the pooled prevalence of HPV infection and cancer risk other than cervix. 
Pooled prevalence of HPV infection other than cervix (Meta-analysis)

The pooled prevalence of HPV infection other than cervix was $34.36 \%$ (95\% CI: 23.75 , 44.97) (Figure 2). As shown in the forest plot below, statistically significant heterogeneity was identified $\left(\mathrm{I}^{2}=99.5 \% ; \mathrm{p}<0.001\right)$ indicating that the use of random effect models for estimating the pooled estimate is applicable. The significant magnitude of the heterogeneity also suggests the need to conduct subgroup analysis to identify the source of heterogeneity (Figure 2).

\section{Subgroup analysis}

Subgroup analysis was done based on study country (Figure 3), study design, publication year and cancer type to identify the possible source of heterogeneity across the studies (Table 2). The subgroup analysis result directed that the source of heterogeneity was not due to study country, publication year, cancer type and detection methods (the overall p-value for each subgroup is less than 0.001 )

Table 1. Characteristics of 22 included studies to estimate the pooled prevalence of HPV infection and cancer risk other than cervix.

\begin{tabular}{|c|c|c|c|c|c|c|c|c|}
\hline ID & Authors & $\begin{array}{l}\text { Publicatio } \\
\text { n year }\end{array}$ & Country & $\begin{array}{l}\text { Study } \\
\text { design }\end{array}$ & $\begin{array}{l}\text { Detection } \\
\text { method }\end{array}$ & $\begin{array}{l}\text { Sample } \\
\text { size }\end{array}$ & $\begin{array}{l}\text { Prevalence } \\
(\%)\end{array}$ & $\begin{array}{l}\text { Cancer } \\
\text { type }\end{array}$ \\
\hline 1 & Gillison et al & 2000 & USA & case control & PCR & 253 & 25 & $\begin{array}{l}\text { Head and } \\
\text { neck } \\
\text { cancer }\end{array}$ \\
\hline 2 & Jatin et al & 2002 & India & $\begin{array}{l}\text { cross } \\
\text { sectional }\end{array}$ & PCR & 110 & 33.6 & Oral cancer \\
\hline 3 & Harwood et al & 2004 & England & case control & PCR & 124 & 62.9 & Skin cancer \\
\hline 4 & Smith et al & 2004 & USA & case control & PCR & 201 & 22.9 & $\begin{array}{l}\text { Head and } \\
\text { neck } \\
\text { cancer }\end{array}$ \\
\hline 5 & Katiyar et al & 2005 & India & $\begin{array}{l}\text { cross } \\
\text { sectional }\end{array}$ & PCR & 101 & 44 & Oral cancer \\
\hline 6 & Moonen et al 1 & 2006 & Netherland & $\begin{array}{l}\text { cross } \\
\text { sectional }\end{array}$ & PCR & 107 & 15.2 & $\begin{array}{l}\text { Bladder } \\
\text { cancer }\end{array}$ \\
\hline 7 & Krustrup et al & 2008 & Denmark & $\begin{array}{l}\text { cross } \\
\text { sectional }\end{array}$ & PCR & 145 & 61 & $\begin{array}{l}\text { Genital } \\
\text { cancer }\end{array}$ \\
\hline 8 & Patel et al & 2008 & Germany & case control & PCR & 239 & 20 & Skin cancer \\
\hline 9 & Escutia et al & 2010 & Spain & case control & PCR & 142 & 21.2 & Skin cancer \\
\hline 10 & Larsson et al & 2012 & Sweden & $\begin{array}{l}\text { cross } \\
\text { sectional }\end{array}$ & PCR & 69 & 53.6 & $\begin{array}{l}\text { Genital } \\
\text { cancer }\end{array}$ \\
\hline 11 & Kiyoshi et al & 2012 & Japan & case control & Hybrid & 30 & 69.2 & Oral cancer \\
\hline 12 & Michuad et al & 2015 & USA & $\begin{array}{l}\text { cross } \\
\text { sectional }\end{array}$ & PCR & 1069 & 14.8 & Oral cancer \\
\hline 13 & Hussein et al & 2016 & Iraq & $\begin{array}{l}\text { cross } \\
\text { sectional }\end{array}$ & PCR & 104 & 12.5 & Any type \\
\hline 14 & Fatemeh et al & 2016 & Iran & $\begin{array}{l}\text { cross } \\
\text { sectional }\end{array}$ & PCR & 200 & 20 & $\begin{array}{l}\text { Prostate } \\
\text { cancer }\end{array}$ \\
\hline 15 & Doosti et al & 2016 & Iran & $\begin{array}{l}\text { cross } \\
\text { sectional }\end{array}$ & PCR & 47 & 22.9 & $\begin{array}{l}\text { Breast } \\
\text { cancer }\end{array}$ \\
\hline 16 & Gheit et al & 2017 & India & $\begin{array}{l}\text { cross } \\
\text { sectional }\end{array}$ & PCR & 364 & 13.7 & $\begin{array}{l}\text { Head and } \\
\text { neck } \\
\text { cancer }\end{array}$ \\
\hline 17 & $\begin{array}{l}\text { Luna-Aguirre et } \\
\text { al }\end{array}$ & 2017 & Mexico & $\begin{array}{l}\text { cross } \\
\text { sectional }\end{array}$ & PCR & 724 & 87 & Any type \\
\hline 18 & $\mathrm{Fu} \mathrm{Xi}$ et al & 2018 & USA & $\begin{array}{l}\text { cross } \\
\text { sectional }\end{array}$ & PCR & 1090 & 5 & Skin cancer \\
\hline 19 & Zhao et al & 2018 & China & $\begin{array}{l}\text { cross } \\
\text { sectional }\end{array}$ & PCR & 3393 & 15.1 & Any type \\
\hline 20 & Agalliu et al & 2019 & USA & case control & PCR & 125 & 75.7 & Oral cancer \\
\hline 21 & Al-lawati et al & 2019 & Oman & $\begin{array}{l}\text { cross } \\
\text { sectional }\end{array}$ & PCR & 258 & 17.8 & Any type \\
\hline 22 & Niloofar et al & 2019 & Iran & case control & PCR & 72 & 48.6 & $\begin{array}{l}\text { Breast } \\
\text { cancer }\end{array}$ \\
\hline
\end{tabular}


Study

ID
Gillison etal (2000)

Jatin K etal (2002)

Harwood etal (2003)

Smith etal (2004)

Katiyar etal (2005)

Moonen etal (2006)

Dorrit etal (2008)

Patel etal (2008)

Escutia etal (2010)

Larsson etal (2012)

Kiyoshi etal (2012)

Michuad etal (2015)

Hussein etal (2016)

Fatemeh etal (2016)

Doosti etal (2016)

Gheit etal (2017)

Luna-Aguirre etal (2017)

$\mathrm{Xi}$ etal (2018)

Zhao etal (2018)

Agalliu etal (2019)

Al-lawati etal (2019)

Niloofar etal (2019)

Overall (I-squared $=99.5 \%, p=0.000$ )

NOTE: Weights are from random effects analysis
ES $(95 \% \mathrm{Cl})$
Weight

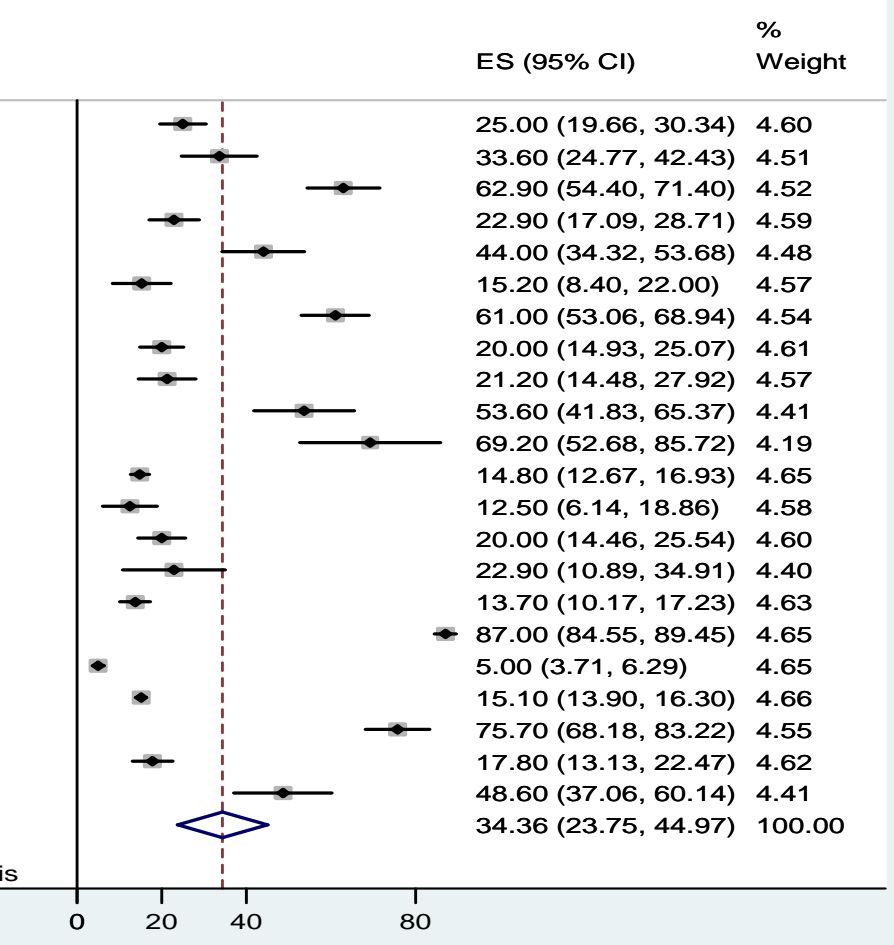

Figure 2. Forest plots showing the pooled prevalence of HPV infection other than cervix.

The lowest pooled prevalence of HPV infection other than cervix was indicated in usa [28.21\% (95\% CI: 14.41, 42.02)] (Figure 3). There was decrement of HPV infection other than cervix starting from 2015 (30.19\% (95\% CI: 14.56, 45.82))
(Table 2). The highest pooled prevalence of HPV infection other than cervix was related to genital cancer, secondly oral cancer is the highest prevalence and breast cancer is in the third rank (Table 2 and Figure 4).

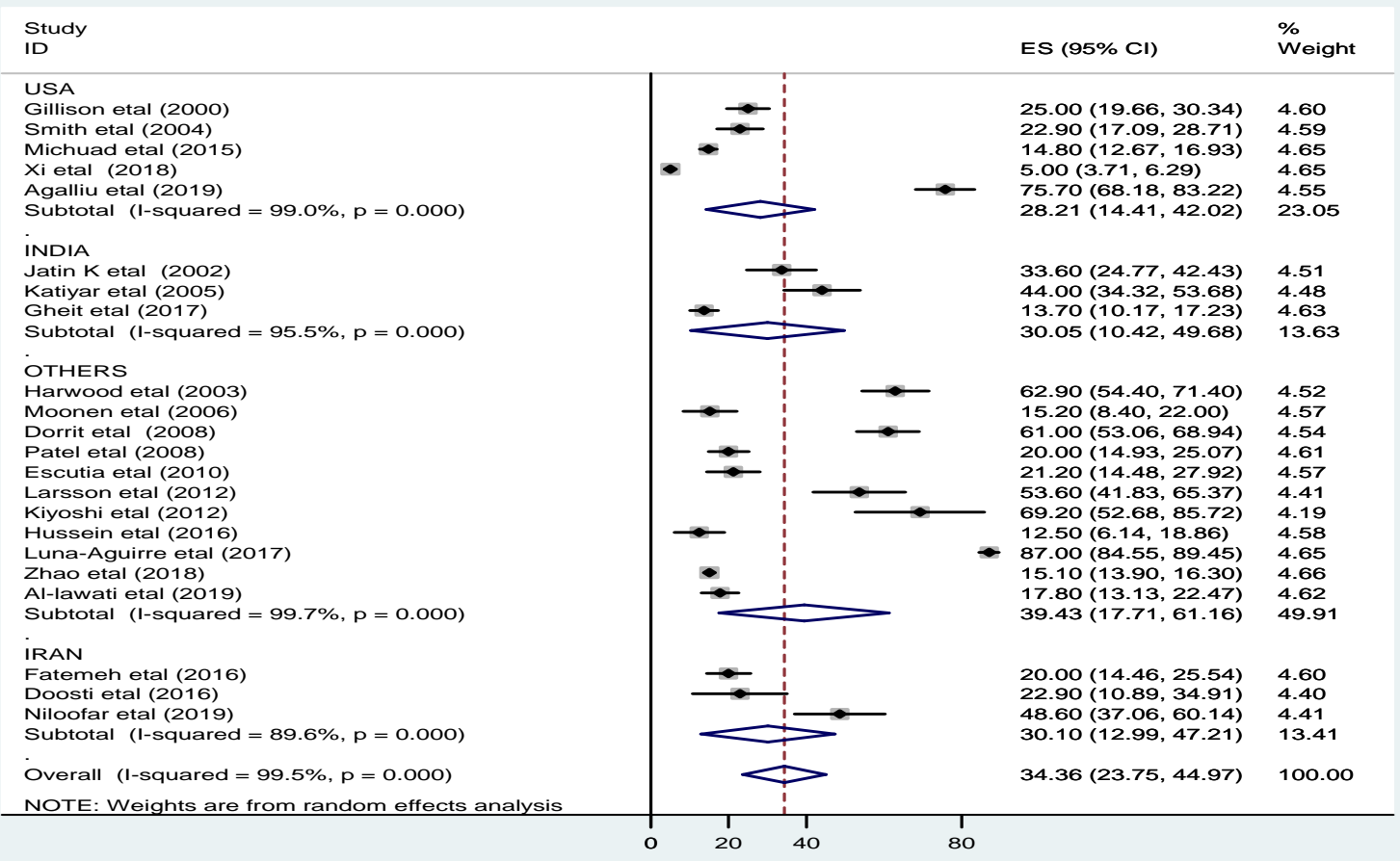

Figure 3. Forest plot shows subgroup analysis of HPV infection other than cervix by country. 
Table 2. Subgroup analysis which indicates the pooled prevalence of HPV infection other than cervix.

\begin{tabular}{|c|c|c|c|c|c|c|}
\hline Subgroups & & $\begin{array}{l}\text { No. of } \\
\text { studies }\end{array}$ & $\begin{array}{l}\text { Prevalence } \\
(95 \% \text { CI })\end{array}$ & $\begin{array}{l}\text { Heterogeneity } \\
\text { statistics }\end{array}$ & $\begin{array}{l}P \\
\text { value }\end{array}$ & $\begin{array}{ll}- & I^{2} \\
& (\%)\end{array}$ \\
\hline \multirow[t]{6}{*}{ Cancer type } & $\begin{array}{l}\text { Head and Neck } \\
\text { cancer }\end{array}$ & 3 & $20.29(12.65,27.94)$ & 14.98 & 0.001 & 86.6 \\
\hline & Oral cancer & 5 & $47.15(19.67,74.63)$ & 297.64 & $<0.001$ & 98.7 \\
\hline & Skin cancer & 4 & $26.95(7.05,46.84)$ & 216.70 & $<0.001$ & 98.6 \\
\hline & Genital cancer & 2 & $58.63(51.86,65.39)$ & 1.04 & 0.307 & 4.2 \\
\hline & Breast cancer & 2 & $35.80(10.62,60.99)$ & 9.14 & 0.003 & 89.1 \\
\hline & Others & 6 & $27.97(-3.39,59.34)$ & 2730.78 & $<0.001$ & 99.8 \\
\hline Detection & PCR & 21 & $32.84(22.03,43.65)$ & 4000.01 & $<0.001$ & 99.5 \\
\hline method & Hybridization & 1 & $69.2(52.68,85.72)$ & 0 & $<0.001$ & 99.5 \\
\hline \multirow[t]{2}{*}{ Study design } & Cross sectional & 14 & $29.62(16.12,43.11)$ & 3656.49 & $<0.001$ & 99.6 \\
\hline & Case control & 8 & $42.65(27.49,57.80)$ & 254.07 & $<0.001$ & 97.2 \\
\hline \multirow[t]{2}{*}{ Publication year } & Before 2015 & 11 & $38.22(27.98,48.46)$ & 210.15 & $<0.001$ & 95.2 \\
\hline & 2015 and above & 11 & $30.19(14.56,45.82)$ & 3722.16 & $<0.001$ & 99.7 \\
\hline
\end{tabular}

Study

Head and Neck cancer

Gillison etal (2000)

Smith etal (2004)

Gubtotal ( $\mathrm{I}$-squared $=86.6 \%, \mathrm{p}=0.001$ )

Oral cancer

Jatin K etal (2002)

Katiyar etal (2005)

Kiyoshi etal (2012)

Michuad etal (2015)

Agalliu etal (2019)

Subtotal (I-squared $=98.7 \%, p=0.000)$

Skin cancer

Harwood etal (2003)

Patel etal (2008)

Escutia etal (2010)

Xi etal (2018)

Subtotal $(\mathrm{I}$-squared $=98.6 \%, \mathrm{p}=0.000)$

Others

Moonen etal (2006)

Hussein etal (2016)

Fatemeh etal (2016)

Luna-Aguirre etal (2017)

Zhao etal (2018)

Al-lawati etal (2019)

Subtotal (I-squared $=99.8 \%, p=0.000)$

Genital cancer

Genital cancer

Dorrit etal (2008)

Larsson etal (2012) $=4.2 \%, \mathrm{p}=0.307$ )

Breast cancer

Doosti etal (2016)

Niloofar etal (2019)

Subtotal $(\mathrm{I}$-squared $=89.1 \%, \mathrm{p}=0.003)$

Overall (I-squared $=99.5 \%, p=0.000$ )

NOTE: Weights are from random effects analysis

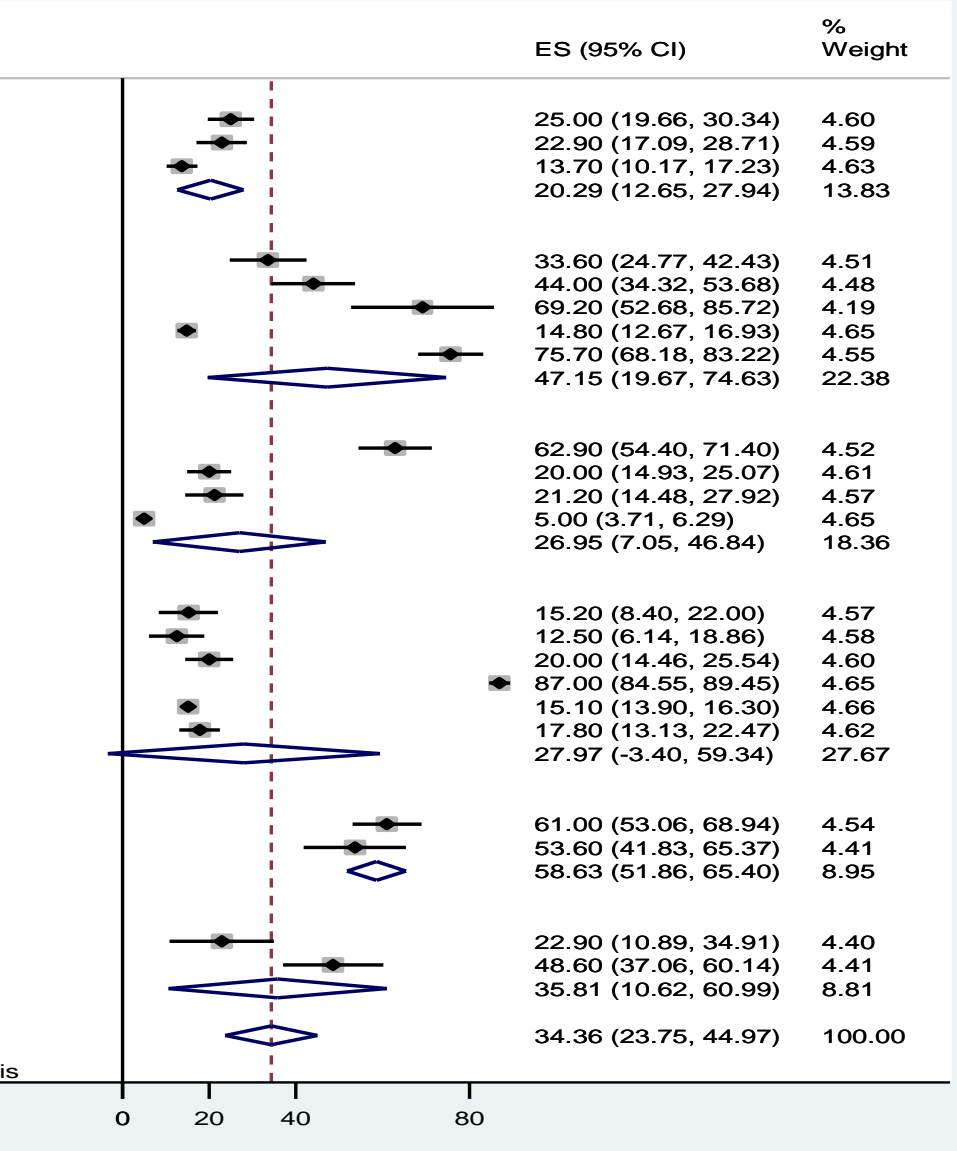

Figure 4. Forest plot shows subgroup analysis of HPV infection other than cervix by cancer type.

\section{Publication bias}

In addition to subgroup analysis, publication bias as source of heterogeneity was also checked using both Begg's and Egger's tests using STATA version 14. The result of Begg and Egger tests were not identified as the source of heterogeneity pooled prevalence of HPV infection other than cervix at $p$-value of $(p=0.003)$ and $(p=0.104)$ respectively.

\section{Meta regression}

Besides subgroup analysis and publication bias, meta regression was also assumed by considering both continuous and categorical data 
to identify associated factor of heterogeneity for the pooled prevalence of HPV infection other than cervix. Study country, sample size, publication year and study design were considered in metaregression. However, the Meta regression indicated that the pooled prevalence of HPV infection other than cervix was not associated with study country, sample size, publication year and study design (Table 3).

Table 3. Meta regression to identify the source of heterogeneity for the prevalence of HPV infection other than cervix.

\begin{tabular}{lllll}
\hline Variables & & $\begin{array}{l}\text { Numbe } \\
\text { r }\end{array}$ & $\begin{array}{l}\text { Coefficient } \\
\text { s }\end{array}$ & P -value \\
\hline $\begin{array}{l}\text { Study } \\
\text { country }\end{array}$ & Iran & 3 & Reference & $\begin{array}{l}\text { Referenc } \\
\text { e }\end{array}$ \\
& USA & 5 & -1.8704 & 0.921 \\
& India & 3 & -0.1106 & 0.996 \\
& Others & 11 & 8.9016 & 0.598 \\
Sample & Sample & 22 & -0.0083 & 0.249 \\
& size & & & \\
Publicatio & Before & 11 & 8.3976 & 0.424 \\
n year & 2015 & & & \\
& 2015 & 11 & Reference & Referenc \\
& and & & & e \\
& above & & & Referenc \\
Study & Case & 8 & Reference & e \\
design & control & & & 0.225 \\
& Cross & 14 & -13.1325 & \\
\hline & sectiona & & & \\
\hline
\end{tabular}

\section{DISCUSSION}

This systematic review and meta-analysis was conducted to estimate the pooled prevalence of HPV infection other than cervix and related types of cancers from 2000 to 2019. According to this systematic review and meta-analysis, more than one third $(34.36 \%)$ of participants were infected with HPV other than cervix. Genital cancers and oral cancers were more frequent related diseases with HPV infection other than cervix. The prevalence of HPV infection other than cervix is decreasing after 2015 based on the meat-analysis result of this study. In this meta- analysis low prevalence of HPV infection other than cervix have been seen in USA compared to India and Iran.

The prevalence of HPV infection other than cervix in this systematic review and metaanalysis is lower than with study done by (Ortiz, Tamayo et al. 2017), (Fernandes, Meissner Rde et al. 2009), (So, Lee et al. 2019) and (Ghosh, Shetty et al. 2019). But it is higher than the study done by (Shrivastava, Agrawal et al. 2015), (Chikandiwa, Pisa et al. 2019), (Guan, Howell-
Jones et al. 2012) and (Ferré, Ekouevi et al. 2019). (de Martel, Plummer et al. 2017) reported than the prevalence of HPV infection was $<3 \%$ in USA and $>20 \%$ India. In this meta-analysis also the prevalence was higher in India than USA. But it is lower than the overall prevalence of HPV in USA and India summarized in this metaanalysis. These disparities may be due to sample size and study methodologies difference between this meta-analysis and other studies.

Regarding the issue HPV infection induced cancers; it is obvious that many research finding reported than cervical cancer primarily associated cancer type. But there are also other cancer types related with HPV infection. A study by (Mirghani, Sturgis et al. 2017) showed that there is an increasing risk tongue or tonsil cancers (oral cancers) which could be an indication of HPV infection in different anatomical locations cause cancers both in men and women.

This meta-analysis study has certain limitations which includes only articles publish in English language and there are also research articles which didn't included to this review due to limitation of access to papers.

\section{CONCLUSION}

Although cervical cancer is primarily HPV induced cancer, other cancer types (based on the location of HPV infection) are also increasing across the world. More than $34.36 \%$ of participants included in this study were infected with HPV other than the cervical region. This increases the risk of development of cancers other than cervix induced by HPV infection. Therefore, countries and health organizations should also give attention to risk of other cancers induced by HPV infection in parallel to cervical cancer.

\section{ACKNOWLEDGMENT}

We would like to thank all authors of studies included in this systematic review and meta-analysis.

\section{REFERENCES}

1. Agalliu, I., Chen, T., Wang, R., Hayes, N., Freedman, S., Gapstur, M and Burk, D (2018). "Oral Alpha, Beta, and Gamma HPV Types and Risk of Incident Esophageal Cancer." Cancer Epidemiol Biomarkers Prev 27: 11681175. 
2. Al-Lawati, Z., Khamis, F., Al-Hamdani, A., AlKalbani, M., Ramadhan, F., Al-Rawahi, T and Al-Kobaisi, M (2020). "Prevalence of human papilloma virus in Oman: Genotypes 82 and 68 are dominating." Int J Infect Dis 93: 22-27.

3. Ammatuna, P., Giovannelli, L., Matranga, D., Ciriminna, S. and Perino, A (2008). "Prevalence of genital human papilloma virus infection and genotypes among young women in Sicily, South Italy." Cancer Epidemiol Biomarkers Prev 17: 2002-2006.

4. Asiaf, A., Ahmad, S., Mohammad M., Zargar, A (2014). "Review of the current knowledge on the epidemiology, pathogenesis, and prevention of human papillomavirus infection." European Journal of Cancer Prevention 23: 206-224.

5. Atashafrooz, F. and Rokhbakhsh-Zamin, F. (2016). "Frequency and Type Distribution of Human Papilloma Virus in Patients with Prostate Cancer, Kerman, Southeast of Iran." Asian Pac J Cancer Prev 17: 3953-3958.

6. Bryan, J. (2007). "Developing an HPV vaccine to prevent cervical cancer and genital warts." Vaccine 25: 3001-3006.

7. Chikandiwa, A., Pisa, P., Sengayi, M., Singh, E and Delany-Moretlwe, S (2019). "Patterns and trends of HPV-related cancers other than cervix in South Africa from 1994-2013." Cancer Epidemiol 58: 121-129.

8. de Martel, C., Plummer, Vignat, V and Franceschi, S (2017). "Worldwide burden of cancer attributable to HPV by site, country and HPV type." Int J Cancer 141: 664-670.

9. Doosti, M., Bakhshesh, M, Zahir, S., Shayestehpour, M and Karimi-Zarchi, M. (2016). "Lack of Evidence for a Relationship between High Risk Human Papillomaviruses and Breast Cancer in Iranian Patients." Asian Pac J Cancer Prev 17: 4357-4361.

10. Escutia, Ledesma, B., Serra-Guillen, Gimeno, C., Vilata, J., Guillén, C. and Nagore, E. (2011). "Detection of human papilloma virus in normal skin and in superficial and nodular basal cell carcinomas in immunocompetent subjects." J Eur Acad Dermatol Venereol 25: 832-838.

11. Fernandes, J., Meissner Rde, V., Carvalho, M., Fernandes, de Azevedo, T. and Villa, L. (2009). "Prevalence of HPV infection by cervical cytologic status in Brazil." Int $J$ Gynaecol Obstet 105: 21-24.

12. Ferré, V., Ekouevi, D., Gbeasor-Komlanvi, F., Collin, G., Le Hingrat, Q., Tchounga, B. Salou, M., Descamps, D., Charpentier, C. and Dagnra, A. (2019). "Prevalence of human papillomavirus, human immunodeficiency virus and other sexually transmitted infections among female sex workers in Togo: a national cross-sectional survey." Clin Microbiol Infect 25: 1560.e1561-1560.e1567.
13. Fu Xi, L., Schiffman, M., Ke, Y., Hughes, J., Galloway, D., He, D., Hulbert, H., Winer, R., Koutsky, L. and Kiviat, N. (2017). "Typedependent association between risk of cervical intraepithelial neoplasia and viral load of oncogenic human papillomavirus types other than types 16 and 18." Int J Cancer 140: $1747-1756$.

14. Gheit, T., Anantharaman, D., Holzinger, D., Alemany, L., Tous, S., Lucas, E., Prabhu, P., Pawlita, M., Ridder, R., Rehm, S., Bogers, J., Maffini, F., Chiocca, S., Lloveras, B., Kumar, R., Somanathan, T., de Sanjosé, S., Castellsagué, X., Arbyn, M., Brennan, P.,. Sankaranarayanan, R., Pillai, Gangane, M. and Tommasino, M. (2017). "Role of mucosal high-risk human papillomavirus types in head and neck cancers in central India." Int J Cancer 141: 143-151.

15. Ghosh, S., Shetty, R., Pattanshetty, S., Mallya, S., Pandey, D., Kabekkodu, S., Kamath, V., Prabhu, N., D'Souza, J. and Satyamoorthy, K (2019). "Human papilloma and other DNA virus infections of the cervix: A population based comparative study among tribal and general population in India." PLoS One 14: e0219173.

16. Gillison, M., Koch, W., Capone, R., Spafford, M., Westra, W., Wu, L., Zahurak, M., Daniel, R., Viglione, M., Symer, D., Shah, K. and Sidransky, D. (2000). "Evidence for a causal association between human papillomavirus and a subset of head and neck cancers." J Natl Cancer Inst 92: 709-720.

17. Guan, P., Howell-Jones, R., Bruni, N,. de Sanjosé, S., Franceschi, S. and Clifford, G. (2012). "Human papillomavirus types in 115,789 HPV-positive women: a meta-analysis from cervical infection to cancer." Int J Cancer 131: 2349-2359.

18. Harwood, C. , Surentheran, T., Sasieni, P., Proby, C., Bordea, C., Leigh, I., Wojnarowska, F., Breuer, J. and McGregor, J. (2004). "Increased risk of skin cancer associated with the presence of epidermodysplasia verruciformis human papillomavirus types in normal skin." Br J Dermatol 150: 949-957.

19. Hussein, N., Balatay, A., Assafi, M. and AlMufty, T. (2016). "High Risk Human Papilloma Virus Genotypes in Kurdistan Region in Patients with Vaginal Discharge." Asian Pac J Cancer Prev 17: 3191-3193.

20. Katiyar, S., Hedau, S., Jain, N., Kar, P., Khuroo, M., Mohanta, J., Kumar, S., Gopalkrishna, V., Kumar, N. and Das, B. (2005). "p53 gene mutation and human papillomavirus (HPV) infection in esophageal carcinoma from three different endemic geographic regions of India." Cancer Lett 218: 69-79.

21. Khodabandehlou, N., Mostafaei, S., Etemadi, A., Ghasemi, A., Payandeh, M., Hadifar, S., Norooznezhad, A., Kazemnejad, A. and 
Moghoofei, M. (2019). "Human papilloma virus and breast cancer: the role of inflammation and viral expressed proteins." BMC Cancer 19: 61.

22. Kontopantelis, E. and Reeves, D. (2010). "metaan: Random-effects meta-analysis." The STATA Journal 10(3): 395-407.

23. Krustrup, D., Jensen, H., van den, Brule, A. and Frisch, M. (2009). "Histological characteristics of human papilloma-virus-positive and negative invasive and in situ squamous cell tumours of the penis." Int J Exp Pathol 90: 182189.

24. Larsson, G., Helenius, L., Andersson, S., Sorbe, B. and Karlsson, M. (2013). "Prognostic impact of human papilloma virus (HPV) genotyping and HPV-16 subtyping in vaginal carcinoma." Gynecol Oncol 129: 406-411.

25. Liberati, A., Altman, D., Tetzlaff, J., Mulrow, C., . Gøtzsche, P., Ioannidis, J., Clarke, M., Devereaux P., Kleijnen, J. and Moher, D. (2009). "The PRISMA statement for reporting systematic reviews and meta-analyses of studies that evaluate healthcare interventions: explanation and elaboration." Bmj 339: b2700.

26. Luna-Aguirre, C., Reyes-Cortés, L., TorresGrimaldo, A., Karr-de-León, S., Cerda-Flores, R., Melo-Nava, B., Aizpuru-Akel, V. and Barrera-Saldaña, H. (2018). "Prevalence of human papillomavirus types in North and Central regions of Mexico." Epidemiol Infect 146: $1724-1730$.

27. Makiyama, K., Hirai, R., Matsuzaki, H. and Ikeda, M. (2013). "Assessment of human papilloma virus infection in adult laryngeal papilloma using a screening test." J Voice 27: 230-235.

28. Michaud, D., Langevin, S., Eliot, M., Nelson, H., Pawlita, M., McClean, M. and Kelsey, K. (2014). "High-risk HPV types and head and neck cancer." Int J Cancer 135: 1653-1661.

29. Mirghani, H., Sturgis, E., Aupérin, A., Monsonego, J. and Blanchard, P. (2017). "Is there an increased risk of cancer among spouses of patients with an HPV-related cancer: A systematic review." Oral Oncol 67: 138-145.

30. Moonen, P., Bakkers, J., Kiemeney, L., Schalken, J., Melchers, W. and Witjes, J. (2007). "Human papilloma virus DNA and p53 mutation analysis on bladder washes in relation to clinical outcome of bladder cancer." Eur Urol 52(2): 464-468.

31. Münger, K., Baldwin, A., Edwards, K., Hayakawa, H., Nguyen, C., Owens, M., Grace,.M. and Huh, K. (2004). "Mechanisms of human papillomavirus-induced oncogenesis." Journal of virology 78(21): 11451-11460.

32. Muñoz, N., Bosch, F., De Sanjosé, S., Herrero, R., Castellsagué, X, Shah, K., Snijders, P. and Meijer, C (2003). "Epidemiologic classification of human papillomavirus types associated with cervical cancer." New England journal of medicine 348: 518-527.

33. Nagpal, J., Patnaik, S and Das, B. (2002). "Prevalence of high-risk human papilloma virus types and its association with P53 codon 72 polymorphism in tobacco addicted oral squamous cell carcinoma (OSCC) patients of Eastern India." Int J Cancer 97: 649653.

34. Ortiz, A., Tamayo, V., Scorsone, A., Soto-Salgado, M., Febo, I., Piovanetti, P., Venegas-Ríos, H., Yamamura, Y. and Zorrilla, C. (2017). "Prevalence and correlates of cervical HPV infection in a clinic-based sample of HIVpositive Hispanic women." Papillomavirus Res 4: 39-44.

35. Parkin, D. (2006). "The global health burden of infection-associated cancers in the year 2002." International journal of cancer 118: 3030-3044.

36. Patel, A., Karagas, M., Pawlita, M., Waterboer, T. and Nelson, H. (2008). "Cutaneous human papillomavirus infection, the EVER2 gene and incidence of squamous cell carcinoma: a case-control study." Int J Cancer 122: 23772379.

37. Schultz, T. and Florence, Z. (2007). Joanna Briggs institute meta-analysis of statistics assessment and review instrument, Adelaide: Joanna Briggs Institute.

38. Serrano, B., Brotons, M., Bosch, F. and Bruni, L. (2018). "Epidemiology and burden of HPVrelated disease." Best practice $\mathcal{E}$ research Clinical obstetrics \& gynaecology 47: 14-26.

39. Shrivastava, S. B., G. Agrawal, M. Mittal and P. Mishra (2015). "Management of Vaginal Cancer." Rev Recent Clin Trials 10: 289-297.

40. Siegler, E., Shiner, M., Segev, Y., Mackuli, L., Lahat, N. and Lavie, O. (2017). "Prevalence and Genotype Distribution of HPV Types in Women at Risk for Cervical Neoplasia in Israel." Isr Med Assoc J 19: 635-639.

41. Small, W., Bacon, M., Bajaj, A., Chuang, L., Fisher, B., Harkenrider, M., Jhingran, A., Kitchener, H., Mileshkin, L., Viswanathan., A. and Gaffney, D. (2017). "Cervical cancer: A global health crisis." Cancer 123: 2404-2412.

42. Smith, E., Ritchie, J., Summersgill, K., Hoffman, H., Wang, D., Haugen, T. and Turek, L. (2004). "Human papillomavirus in oral exfoliated cells and risk of head and neck cancer." J Natl Cancer Inst 96: 449-455.

43. So, K. A., Lee, I., K. H. Lee, K., Hong, S., Kim, Y., Seo, H. and Kim, T. (2019). "Human papillomavirus genotype-specific risk in cervical carcinogenesis." J Gynecol Oncol 30: e52.

44. Sutton, A., Abrams, K., Jones, D., Jones, D., Sheldon, T. and Song, F. (2000). Methods for meta-analysis in medical research, Wiley Chichester. 
45. Tadlaoui, K., Hassou, N., Bennani, B. and Ennaji, M. (2020). Emergence of Oncogenic HighRisk Human Papillomavirus Types and Cervical Cancer. Emerging and Reemerging Viral Pathogens, Elsevier: 539-570.

46. Tate, M. and Brown, S. (1970). "Note on the Cochran Q test." Journal of the American Statistical Association 65: 155-160.

47. Woodman, C., Collins, S. and Young, L. (2007). "The natural history of cervical HPV infection: unresolved issues." Nature Reviews Cancer 7: 11-22.
48. Yete, S., D'Souza, W. and Saranath, D. (2018). "High-Risk Human Papillomavirus in Oral Cancer: Clinical Implications." Oncology 94: 133-141.

49. Zhao, Y., Wu, K., Tong, H., Liu, Y., Zha, H., H. Yue, H., Zhang, J. and X. Liu, X (2018). "Genotype patterns and prevalence of human papilloma virus in non-vaccinated women in Zunyi, China." Saudi Med J 39: 572-578. 